\title{
FAKTOR-FAKTOR YANG BERHUBUNGAN DENGAN KEJADIAN DEPRESI PADA LANSIA DI POSYANDU LANSIA DESA JAKE WILAYAH KERJA UPTD KESEHATAN KARI KABUPATEN KUANTAN SINGINGI TAHUN 2016
}

\author{
Alini \\ Dosen FIK Universitas Pahlawan Tuanku Tambusai, Riau, Indonesia \\ Alini_09@yahoo.com
}

\begin{abstract}
ABSTRAK
Peningkatan angka harapan hidup merupakan indikator kemajuan suatu bangsa, akan tetapi hal tersebut menimbulkan suatu masalah, terutama masalah kesehatan dan kerawanan sosial akibat banyaknya lansia yang terlantar. Kelompok lansia dipandang sebagai kelompok masyarakat yang berisiko mengalami gangguan kesehatan jiwa yaitu depresi. Tujuan penelitian ini adalah untuk mengetahui faktor-faktor yang berhubungan dengan kejadian depresi pada lansia. Penelitian ini menggunakan rancangan descriptitive correlational dengan pendekatan cross sectional. Populasi dalam penelitian ini adalah seluruh lansia yang ada di Desa Jake Wilayah Kerja UPTD Kesehatan Kari. Teknik pengambilan sampel yang digunakan adalah total sampling dengan menjadikan seluruh lansia di Posyandu Lansia Desa Jake yang berjumlah 58 orang sebagai sampel. Pengumpulan data menggunakan kuesioner. Hasil penelitian menunjukan bahwa ada hubungan antara jenis kelamin dengan depresi pada lansia $(\mathrm{Pv}=0,000)$, ada hubungan antara pekerjaan dengan depresi pada lansia $(\mathrm{Pv}=0,001)$ ada hubungan antara status perkawinan dengan depresi pada lansia $(\mathrm{Pv}=0,004)$ dan ada hubungan antara dukungan keluarga dengan depresi pada lansia ( $\mathrm{Pv}=0,003)$. Diharapkan kepada kader posyandu lansia memberikan bimbingan dan arahan kepada lansia, serta petugas kesehatan memberikan informasi dan penyuluhan terhadap lansia, mengingat kejadian depresi yang bisa saja dialami oleh responden atau lansia.
\end{abstract}

Daftar Bacaan : 48 (2001-2016)

Kata Kunci : Depresi, Dukungan Keluarga, Jenis Kelamin, Lansia, Pekerjaan, dan Status Perkawinan 


\section{PENDAHULUAN}

\section{Latar Belakang}

Penduduk lanjut usia (lansia) merupakan bagian dari anggota keluarga dan anggota masyarakat yang semakin bertambah jumlahnya sejalan dengan peningkatan usia harapan hidup. Pertumbuhan penduduk lansia di seluruh dunia berjalan sangat cepat dibandingkan dengan kelompok usia lain. Pertumbuhan tersebut akan sangat mengejutkan, yang disebut sebagai "Era Lansia" (Bappenas, BPS, UNFPA, 2005). Menurut Undang-undang No. 13 Tahun 1998 tentang kesejahteraan lanjut usia, lanjut usia adalah seseorang yang telah mencapai usia 60 tahun ke atas (Depsos, 2004).

Sesuai data dari Departemen Sosial bahwa pada abad ke-21 dikenal sebagai kurun penduduk menua atau Era of Population Ageing (Hawari, 2007). Pada tahun 2000 penduduk usia lanjut di seluruh dunia diperkirakan sebanyak 426 juta atau sekitar 6,8\%. Jumlah ini akan meningkat hampir dua kali lipat pada tahun 2025, yaitu menjadi sekitar 828 juta jiwa atau sekitar 9,7\% dari total penduduk dunia. Di Negara-negara maju, jumlah lansia juga ternyata mengalami peningkatan, antara lain : Jepang $(17,2 \%)$, Singapura $(8,7 \%)$, Hongkong $(12,9)$, dan Korea Selatan $(7,5 \%)$ sudah cukup besar sejak decade 1990-an. Sementara Negaranegara seperti Belanda, Jerman dan Prancis sudah lebih dulu menghadapi masalah yang serupa. Lansia sebagai tahap akhir dari siklus kehidupan manusia, sering diwarnai dengan kondisi hidup yang tidak sesuai dengan harapan. (Syamsuddin, 2006).

Salah satu hasil pembangunan kesehatan di Indonesia adalah meningkatnya angka harapan hidup (lifeexpectancy). Dilihat dari sisi ini, pembangunan kesehatan di Indonesia sudah cukup berhasil karena angka harapan hidup bangsa kita telah meningkat secara bermakna. Namun disisi lain dengan meningkatnya angka harapan hidup ini membawa beban bagi masyarakat karena populasi penduduk lanjut usia (lansia) meningkat. Hal ini berarti kelompok resiko dalam masyarakat kita menjadi lebih tinggi. Meningkatnya populasi lansia ini bukan hanya fenomena di Indonesia saja, tetapi juga secara global (Notoatmodjo, 2007).
Pertumbuhan jumlah penduduk lansia di Indonesia tercatat sebagai paling pesat di dunia. Pada tahun 2000, Indonesia merupakan negara urutan ke-4 dengan jumlah lansia paling banyak sesudah Cina, India dan USA. Berdasarkan sensus penduduk yang diperoleh bahwa pada tahun 2000 jumlah lansia mencapai 15,8 juta jiwa atau 7,6\%. Pada tahun 2005 diperkirakan jumlah lansia menjadi 18,2 juta jiwa atau $8,2 \%$ dan pada tahun 2015 menjadi 24,4 juta jiwa atau $10 \%$.

Hasil survei Badan Pusat Statistik (BPS) jumlah lansia di Indonesia sebanyak 17.717.800 jiwa atau $7,90 \%$ (BPSSusenas 2006), dan diperkirakan pada tahun 2010 jumlah lansia bertambah menjadi $9,77 \%$ atau sebanyak 23.992.552 jiwa dan pada tahun 2020 diperkirakan bertambah menjadi 28.822 .879 jiwa atau $11,34 \%$. Jumlah lanjut usia yang bertambah membuat Indonesia merupakan negara yang berpenduduk struktur tua karena jumlah penduduk lanjut usia (lansia) di Indonesia sudah di atas 7\% dan dalam kurun waktu 1990 2010. Dalam hal berpenduduk struktur tua Indonesia berada di urutan keempat setelah China, India, dan Amerika Serikat (Martono, 2008).

Jumlah penduduk Kuansing pada tahun 2015 sekitar 357.381 jiwa, untuk laki-laki 183.965 jiwa tahun dan wanita 173.416 jiwa tahun (Badan Pusat Statistik, 2015) dengan jumlah penduduk lanjut usia sekitar 22,6\% (Dinas Kesehatan Kuantan Singingi, 2015). Peningkatan harapan hidup tersebut disatu pihak menjadi indikator kemajuan suatu bangsa, tetapi dipihak lain akan banyak menimbulkan masalah terutama masalah kesehatan dan kerawanan sosial akibat banyaknya lansia yang terlantar. Penanganan yang tidak bijaksana akan menimbulkan masalah baru terutama secara psikologis lansia tidak mendapat tempat secara sosial di masyarakat (Hawari, 2007).

Kelompok lansia dipandang sebagai kelompok masyarakat yang beresiko mengalami gangguan kesehatan, termasuk masalah kesehatan jiwa yaitu gangguan depresi (Departemen Kesehatan Republik Indonesia, 2004). Sejauh ini, prevalensi depresi pada lansia di dunia berkisar $8 \%-15 \%$ dan hasil meta analisis dari laporan negara-negara di dunia mendapatkan prevalensi rata-rata depresi pada lansia adalah $13,5 \%$ dengan 
perbandingan wanita-pria 14,1:8,6. Adapun prevalensi depresi pada lansia yang menjalani perawatan di rumah sakit dan panti perawatan sebesar 30-45 persen (Kompas, 2008). Menurut hasil survey World Health Organization (WHO) 1990 setiap tahunnya terdapat 100 juta kasus depresi (Handajani, 2003). Diperkirakan dimasa mendatang (2020) pola penyakit Negara berkembang akan berubah, yaitu depresi berat unipolar akan menggantikan penyakit-penyakit saluran pernafasan bawah sebagai urutan teratas (Amir, 2005).

Depresi adalah gangguan afek yang sering terjadi pada lansia dan merupakan salah satu gangguan emosi. Gejala depresi pada lansia dapat terlihat seperti lansia mejadi kurang bersemangat dalam menjalani hidupnya, mudah putus asa, aktivitas menurun, kurang nafsu makan, cepat lelah dan susah tidur dimalam hari (Nugroho, 2006). Lansia yang mengalami depresi akan mengakibatkan kesulitan dalam memenuhi kebutuhan aktivitas sehari-harinya (Palestin, 2006). Depresi merupakan gangguan mental yang paling banyak menimbulkan beban disabilitas, meningkatkan morbiditas, mortalitas, dan resiko bunuh diri. Depresi juga dikaitkan dengan faktor sosiodemografi seseorang. Hal ini dijelaskan dalam Canadian Community Health Survey yang menyatakan bahwa terdapat perbedaan tingkat depresi antara perempuan dan laki-laki, jenis kelamin, pekerjaan, status perkawinan, dukungan keluarga. (Canadian Medical Association Journal, 2000).

Menurut World Health Organization (WHO) pada tahun 2010 prevalensi keseluruhan terjadinya gangguan depresi pada lansia bervariasi, antara $10 \%$ hingga 20\%, yaitu sekitar 7 juta dari 39 juta, walaupun pada kasus ini depresi berat jarang terjadi. Angka prevalensi depresi pada lansia di Indonesia cukup tinggi yaitu sebesar $17,8 \%$, dan hasil sensus tahun 2010 menunjukkan jumlah lansia yang tinggal di perkotaan lebih besar yaitu 15.714.952 (11,20\%) dibandingkan dengan yang tinggal di pedesaan yaitu sebesar 13.107.927 $(10,21 \%)$. Permasalahan yang dialami lansia adalah gangguan mental yaitu depresi.
Menurut Nugroho (2003), lanjut usia yang mengalami depresi dengan gejala umum yaitu kurang atau hilangnya perhatian diri, keluarga atau lingkungan. Oleh karenanya, dalam menghadapi permasalahan di atas beruntunglah lansia yang masih memiliki keluarga. Keberadaan anggota keluarga seperti anak, cucu, cicit maupun sanak saudara yang lain yang masih memperhatikan, membantu (care) dan peduli dengan permasalahan yang dihadapi lansia. Namun bagi lansia yang hidup sendiri, telah kehilangan pasangan, memiliki pasangan tapi tidak punya anak, berada jauh dari anak- anak (rantauan) akan membuat lansia merasa kesepian, sendiri, tidak ada perhatian dari lingkungan.

Salah satu kebijakan Departemen Kesehatan RI dalam pembinaan usia lanjut adalah dengan upaya peningkatan kesehatan dan kemampuan untuk mandiri agar selama mungkin dapat produktif dan berperan aktif dalam pembangunan. Upaya pembinaan kesehatan lansia dilaksanakan melalui program posyandu lansia yang merupakan kerjasama antara lintas program dan lintas sektoral. Untuk mendapatkan hasil yang maksimal dibutuhkan peran serta aktif lanjut usia untuk mengikutinya. Kegiatan posyandu lansia dilakukan untuk meningkatkan kesehatan lanjut usia, termasuk kesehatan jiwanya, serta meningkatkan kesadaran masyarakat terhadap keberadaan lanjut usia (Depkes RI, 2004).

Berbagai kegiatan dan program posyandu lansia sangat berguna bagi kesehatan lansia, salah satunya kesehatan jiwanya, dengan adanya posyandu lansia dapat memungkinkan para lansia dapat berkumpul sesama lansia, serta dapat saling berbagi cerita yang dapat mengurangi beban psikologis yang mereka alami. Juga dapat memperoleh penjelasan tentang kesehatan dan penyuluhan dari para tenaga medis yang ada di posyandu lansia.

Hasil wawancara terhadap 20 orang lansia pada tanggal 5 April 2016 yang mengikuti posyandu lansia di Desa Jake Wilayah Kerja UPTD Kesehatan Kari Kebupaten Kuantan Singingi, menunjukkan bahwa 20 orang lansia yang berjenis kelamin perempuan memiliki beberapa dari gejala depresi dimana mereka mengungkapkan tentang kondisi 
yang dialaminya dan bercerita tentang kehidupannya. Selain itu sebagian besar lansia yang tidak bekerja ternyata lebih banyak yang memiliki gejala depresi karena sudah tidak dapat memperoleh penghasilan sendiri sehingga harus menggantungkan kehidupannya dalam mencukupi kebutuhan sehari-hari pada anak-anaknya maupun cucu-cucunya. Beberapa permasalahan yang dihadapi oleh lansia diatas dapat menjadikan mereka mengalami depresi.

Permasalahan lain yang dihadapi oleh lansia yang bertempat tinggal di Desa Jake Kabupaten Kuantan Singingi, mereka juga kurang dalam mendapatkan perhatian dan dukungan dari keluarga. Hal ini disebabkan oleh kesibukan dari anak-anaknya, tempat tinggal yang jauh sehingga anak jarang untuk mengunjungi, adanya permasalahan antara orangtua dengan anaknya dan anak tidak mau direpotkan dengan urusan orangtuanya serta orang tua sudah jarang dilibatkan dalam penyelesaian masalah yang ada dalam keluarga. Dari penyebab itu lansia merasa sudah tidak dibutuhkan lagi, tidak berguna, tidak dihargai didalam keluarganya dan merasa menjadi beban bagi keluarganya.

Berdasarkan studi pendahuluan dengan wawancara dan observasi ada sekitar 20 lansia, 8 orang diantaranya berusia dari 55-64 tahun berjenis kelamin perempuan dan diantaranya adalah IRT dan tidak memiliki pekerjaan tetapi yang memiliki tanda ataupun gejala dari depresi, dimana mereka kelihatan murung dan sedih. Sementara 7 orang diantaranya berusia 55-64 tahun berjenis kelamin laki-laki yang berkerja sebagai tani, pensiunan pegawai negeri dan bertukang memiliki tanda ataupun gejala depresi yang lain yaitu letih, tidak bergairah, kadang nafsu makan menurun, dan 5 orang diantaranya yang berusia > 64 tahun dan 2 orang diantara 5 orang tersebut berjenis kelamin laki-laki, serta 3 orang berjenis kelamin perempuan dan tidak memiliki pekerjaan tetap, serta sudah tidak memiliki pasangan hidup lagi memiliki tanda ataupun gejala dari depresi yaitu tidak dapat tidur nyenyak dan lebih sering menyendiri.

Adanya permasalahan tersebut maka peneliti tertarik untuk meneliti faktorfaktor yang berhubungan dengan kejadian depresi pada lansia di Posyandu Lansia Wilayah Kerja UPTD Kesehatan Kari, Kabupaten Kuantan Singingi.

\section{Rumusan Masalah}

Berdasarkan uraian masalah pada latar belakang diatas, maka dirumuskan masalah penelitian yaitu : "Faktor-faktor apakah yang berhubungan dengan kejadian depresi pada lansia di Posyandu Lansia Desa Jake Wilayah Kerja UPTD Kesehatan Kari Tahun 2016?".

\section{Tujuan Penelitian}

\section{Tujuan Umum}

Untuk mengetahui faktor-faktor apa saja yang berhubungan dengan depresi pada lansia di Posyandu Lansia Desa Jake Wilayah Kerja UPTD Kesehatan Kari, Kabupaten Kuantan Singingi.

\section{Tujuan Khusus}

a. Mengetahui distribusi frekuensi jenis kelamin, pekerjaan, status perkawinan dan dukungan keluarga terhadap kejadian depresi pada lansia di Posyandu Lansia Desa Jake Wilayah Kerja UPTD Kesehatan Kari, Kabupaten Kuantan Singingi;

b. Mengetahui hubungan antara jenis kelamin dengan kejadian depresi pada lansia di Posyandu Lansia Desa Jake Wilayah Kerja UPTD Kesehatan Kari, Kabupaten Kuantan Singingi;

c. Mengetahui hubungan antara pekerjaan dengan kejadian depresi pada lansia di Posyandu Lansia Desa Jake Wilayah Kerja UPTD Kesehatan Kari, Kabupaten Kuantan Singingi;

d. Mengetahui hubungan antara status perkawinan dengan kejadian depresi pada lansia di Posyandu Lansia Desa Jake Wilayah Kerja UPTD Kesehatan Kari, Kabupaten Kuantan Singingi;

e. Mengetahui hubungan antara dukungan keluarga dengan kejadian depresi pada lansia di Posyandu Lansia Desa Jake Wilayah Kerja UPTD Kesehatan Kari, Kabupaten Kuantan Singingi.

\section{METODE PENELITIAN \\ Desain Penelitian}

Penelitian ini menggunakan rancangan descriptive correlational dengan pendekatan cross sectional. Desain yang digunakan pada penelitian ini bertujuan untuk menggambarkan tentang hubungan antara jenis kelamin, pekerjaan, status perkawinan dan dukungan keluarga 
dengan tingkat depresi pada lanjut usia di Posyandu Lansia Desa Jake Wilayah Kerja UPTD Kesehatan Kari Tahun 2016.

\section{Lokasi dan Waktu Penelitian}

Penelitian ini dilakukan di Posyandu Lansia Desa Jake Wilayah Kerja UPTD Kesehatan Kari, Kabupaten Kuantan Singingi pada tanggal 07 Juni 2016 sampai dengan 07 Juli tahun 2016.

\section{Populasi}

Populasi dalam penelitian ini adalah seluruh lansia yang ada di Desa Jake wilayah kerja UPTD Kesehatan Kari yang berjumlah 58 orang lansia.

\section{Sampel.}

Sampel penelitian ini adalah seluruh lansia yang tinggal di Desa Jake Wilayah Kerja UPTD Kesehatan Kari dengan teknik pengambilan sampel total sampling yaitu pengambilan sampel dengan mengambil seluruh anggota populasi.

\section{Alat Pengumpulan Data}

Alat pengumpulan data yang digunakan pada penelitian adalah kuesioner. Kuisioner yang digunakan untuk karakteristik responden terdiri dari enam pertanyaan yang meliputi : nama, usia, jenis kelamin, status perkawinan, pekerjaan, dan agama. Kuesioner dukungan keluarga terdiri dari 20 pernyataan yang berbeda semua, kuisioner ini menggunakan kuisioner yang dikembang Suwardiman (2011), sehingga tidak perlu dilakukan uji validitas dan reliabilitasnya. Sedangkan kuesioner untuk menentukan kejadian depresi pada lansia menggunakan Geriatrik Depression Scale (GDS) versi Indonesia yang terdiri dari 30 pertanyaan, sehingga tidak diperlukan lagi uji validitas dan realiabilitas.

\section{Analisa Data \\ Analisa yang digunakan adalah analisa univariat dan analisa bivariat. Analisis bivariat menggunakan uji chi-square dengan tingkat kepercayaan $95 \%$ dan tingkat kemaknaan $\mathrm{p}$ value $<0,05$. Analisa data menggunakan bantuan program komputerisasi.}

\section{HASIL PENELITIAN}

Berdasarkan hasil penelitian yang telah dilakukan , maka diperoleh hasil sebagai berikut :

Analisa Univariat
Berdasarkan hasil penelitian dapat diketahui bahwa dari 58 responden lansia di Posyandu Lansia Desa Jake Wilayah Kerja UPTD Kesehatan Kari Kabupaten Kuantan Singingi Tahun 2016, sebagian besar responden berjenis kelamin perempuan yaitu sebanyak 47 responden $(81,0 \%)$, sebagian responden tidak bekerja yaitu sebanyak 30 responden $(51,7 \%)$, sebagian besar responden tidak mempunyai pasangan yaitu sebanyak 41 responden $(70,7 \%)$, dan sebagian besar responden tidak ada dukungan keluarga yaitu sebanyak 43 responden $(74,1 \%)$ serta sebagian besar responden pada lansia di Posyandu Lansia Desa Jake yang mengalami depresi sebanyak 45 responden $(77,6 \%)$.

\section{Analisa Bivariat}

Analisa bivariat dilakukan dengan menggunakan uji chi square.

a. Hubungan Jenis Kelamin dengan Depresi Pada Lansia di Posyandu Lansia Desa Jake Wilayah Kerja UPTD Kesehatan Kari Kabupaten Kuantan Singingi Tahun 2016.

Berdasarkan hasil penelitian diketahui bahwa dari 47 responden yang berjenis kelamin perempuan, terdapat 11 responden $(23,4 \%)$ yang tidak mengalami depresi. Sedangkan dari 11 responden yang berjenis kelamin laki-laki, diketahui sebanyak 9 responden $(81,8 \%)$ yang mengalami depresi. Hasil uji statistik diperoleh nilai $P$ value $=0,000$ ( $p$ value $<$ 0,05), maka dapat disimpulkan ada hubungan yang signifikan antara jenis kelamin dengan depresi pada lansia. Dari hasil analisis diperoleh nilai POR $=1,375$ artinya lansia dengan jenis kelamin perempuan mempunyai risiko $1,375 \mathrm{kali}$ mengalami depresi dibandingkan lansia berjenis kelamin laki-laki.

b. Hubungan Pekerjaan dengan Depresi Pada Lansia di Posyandu Lansia Desa Jake Wilayah Kerja UPTD Kesehatan Kari Kabupaten Kuantan Singingi Tahun 2016

Berdasarkan hasil penelitian dapat diketahui bahwa dari 30 responden yang tidak bekerja, terdapat 11 responden $(36,7 \%)$ yang tidak mengalami depresi. Sedangkan dari 28 responden yang memiliki pekerjaan, terdapat 26 responden $(92,9 \%)$ yang mengalami depresi. Hasil uji statistik diperoleh $P$ value $=0,001(p$ value $<0,05)$, maka 
dapat disimpulkan ada hubungan yang signifikan antara jenis pekerjaan dengan depresi pada lansia. Dari hasil analisi diperoleh $\mathrm{POR}=0,010$ artinya lansia yang tidak bekerja mempunyai risiko 1,333 kali mengalami depresi dibandingkan lansia yang memiliki pekerjaan.

\section{c. Hubungan Status Perkawinan dengan Depresi Pada Lansia di Posyandu Lansia Desa Jake Wilayah Kerja UPTD Kesehatan Kari Kabupaten Kuantan Singingi Tahun 2016}

Berdasarkan hasi penelitian dapat diketahui bahwa dari 41 responden yang tidak mempunyai pasangan, terdapat 7 responden $(17,1 \%)$ yang tidak mengalami depresi. Sedangkan dari 17 responden yang mempunyai pasangan, terdapat 11 responden $(64,7 \%)$ yang mengalami depresi.

Hasil uji statistik menunjukkan nilai $P$ value $=0,004$ ( $p$ value $<0,05)$, sehingga dapat disimpulkan ada hubungan yang signifikan antara status pasangan dengan depresi pada lansia. Dari hasil analisa diperoleh nilai $\mathrm{POR}=7,377$ artinya lansia yang tidak mempunyai pasangan mempunyai risiko 7,377 kali untuk mengalami depresi dibandingkan lansia yang memiliki pasangan.

\section{d. Hubungan Dukungan Keluarga} dengan Depresi Pada Lansia di Posyandu Lansia Desa Jake Wilayah Kerja UPTD Kesehatan Kari Kabupaten Kuantan Singingi Tahun 2016

Berdasarkan hasil penelitian diketahui bahwa bahwa dari 43 responden yang tidak memiliki dukungan keluarga, terdapat 9 responden $(20,9 \%)$ yang tidak mengalami depresi. Sedangkan dari 15 responden yang memiliki dukungan keluarga, terdapat 11 responden $(73,3 \%)$ yang mengalami depresi. Hasil uji statistik menunjukkan nilai $P$ value $=$ 0,003 ( $p$ value < 0,05), maka dapat disimpulkan ada hubungan yang signifikan antara dukungan keluarga dengan depresi pada lansia. Dari hasil analisi diperoleh nilai $\mathrm{POR}=7,728$ artinya responden yang tidak mempunyai dukungan keluarga mempunyai risiko 7,728 kali mengalami depresi dibandingkan dengan responden yang mempunyai dukungan keluarga.

\section{PEMBAHASAN}

a. Hubungan Jenis Kelamin dengan Kejadian Depresi Pada Lansia di Posyandu Lansia Desa Jake Wilayah Kerja UPTD Kesehatan Kari Kabupaten Kuantan Singingi Tahun 2016

Berdasarkan hasil penelitian dilapangan ditemukan bahwa ada hubungan yang bermakna antara jenis kelamin dengan depresi pada lansia. Hal ini dapat disimpulkan bahwa jenis kelamin akan mempengaruhi depresi pada lansia dengan $p$ value 0,000 ( $p$ value $<0,05)$ dan nilai $\mathrm{POR}=1,375$.

Menurut Misba (2010), jenis kelamin mempunyai hubungan dengan kejadian depresi perbedaan gender dalam perkembangan gangguan emosional sangat dipengaruhi oleh persepsi mangenai ketidak mampuan untuk mengontrol, sumber perbedaan ini bersifat kultural karena peran jenis yangberbeda untuk laki-laki dan perempuan dimasyarakat kita. Penelitian ini sejalan dengan penelitian Hermanto (2010), tentang hubungan dukungan keluarga dan jenis kelamin dengan kejadian depresi pada lansia di Posyandu Lansia Semarang yang menyatakan bahwa dari 120 responden yang diteliti jenis kelamin yaitu sebanyak $95(82,4 \%)$ responden dengan hasil perhitungan menunjukkan $(P$ value $=0,000)$ karena nilai signifikan lebih kecil dari nilai $\alpha$ $(0,000<0,05)$ maka dinyatakan terdapat hubungan yang signifikan antara jenis kelamindengan kejadian depresi dengan nilai $\mathrm{OR}=1,150$.

Menurut hasil penelitian Miswanti (2012), tentang status pasangan dan jenis kelamin terhadap kejadian depresi lansia di posyandu lansia di Aceh Selatan diketahui bahwa responden yang jenis kelamin sebanyak $71 \quad(91,7 \%)$ yang mengalami depresi dengan $p$ value $=$ 0,003 . Hasil penelitian ini sejalan juga dengan penelitian Rudiyanti (2012), yang menyatakan bahwa ada hubungan yang bermakna antara jenis kelamin dengan depresi pada lansia dengan hasil analisa ( $p$ value $=0,001$ dan nilai $(\mathrm{OR}=4,105)$.

Menurut asumsi peneliti terdapat 9 responden berjenis kelamin laki-laki mengalami depresi dikarenakan tidak 
adanya dukungan keluarga atau perhatian keluarga terhadap responden sehingga responden mengalami depresi dan 2 responden yang berjenis kelmain laki-laki tidak mengalami depresi dikarenakan oleh adanya dukungan keluarga dan tidak adanya gangguan ataupun permasalahan yang dihadapi oleh responden sehingga responden tidak mengalami depresi melainkan hidup dengan bahagia, sedangakan jenis kelamin perempuan terdapat 36 responden mengalami depresi dikarenakan responden di masa sekarang ini banyak mengalami permasalahan dengan keluarganya sehingga responden mengalami depresi dan 11 berjenis kelamin perempuan tidak mengalami depresi dikarenakan responden tidak ada yang masalah yang berarti dan mempunyai dukungan keluarga yang membimbingnya sehingga responden tidak ada menggalami depresi.

\section{b. Hubungan Pekerjaan dengan Depresi Pada Lansia di Posyandu Lansia Desa Jake Wilayah Kerja UPTD Kesehatan Kari Kabupaten Kuantan Singingi Tahun 2016}

Berdasarkan hasil penelitian dilapangan ditemukan bahwa ada hubungan yang bermakna antara pekerjaan dengan depresi pada lansia. Hal ini dapat disimpulkan bahwa pekerjaan akan mempengaruhi depresi pada lansia dengan $p$ value 0,001 ( $p$ value $<0,05)$ dan nilai $\mathrm{OR}=1,333$.

Menurut teori aktifitas menyatakan bahwa lanjut usia sukses adalah mereka yang aktif dan ikut banyak kegiatan sosial, pada penelitian yang dilakukan oleh Wong dan Almeidah (2012) bahwa status pekerjaan berhubungan dengan depresi dimana lansia yang masih bekerja memiliki resiko terhadap depresi karena waktu mereka lebih banyak dihabiskan untuk berpartisipasi didalam kegiatan sosial berkumpu dengan keluarga dan rekresai pun menjadi berkurang.

Penelitian ini sejalan dengan penelitian Karmila (2010), tentang hubungan, sikap dan pekerjaan kejadian depresi pada lansia di posyandu lansia Kediri menyatakan bahwa dari 167 responden yang tidak memiliki pekerjaan yaitu sebanyak $95(82,4 \%)$ responden dengan hasil perhitungan menunjukkan ( $P$ value $=1,302)$ karena nilai signifikan lebih besar dari nilai $\alpha(1,302>0,05)$ maka dinyatakan terdapat hubungan yang signifikan antara pekerjaan dengan depresi pada lansia dengan nilai $\mathrm{OR}=$ 0,069 .

Penelitian ini sejalan dengan penelitian Misanto (2010), tentang hubungan jenis kelamin mempengaruhi kejadian depresi pada lansia di Solo menyatakan bahwa dari 120 responden yang diteliti sikap negatif yaitu sebanyak $76 \quad(86,9 \%)$ responden dengan hasil perhitungan menunjukkan $\quad(P$ value $=0,000)$ karena nilai signifikan lebih kecil dari nilai $\alpha(0,000<0,05)$ maka dinyatakan terdapat hubungan yang signifikan antara pekerjaan dengan kejadian depresi pada lansia dengan nilai $\mathrm{OR}=2,150$.

Menurut asumsi peneliti terdapat 19 responden yang tidak bekerja mengalami depresi dikarenakan adanya larangan oleh keluarga agar responden tidak menelakukan pekerjaaan sedangkan responden ingin melakukan pekerjaan supaya tidak mengalami depresi atau hal lainnya karena larangan dari keluarga ataupun tidak ada dukungan dari keluarga terhadap responden akhirnya responden mengalami depresi sedangkan 26 responden yang bekerja mengalami depresi dikarenakan responden terlalu capek dan lelah sehingga tidak bisa mengontrol emosionalnya dan tidak adanya dukungan dari keluarga sehingga responden mengalami depresi akibat terlalu banyak yang diipikirkannya.

\section{c. Hubungan Status Perkawinan dengan Depresi Pada Lansia di Posyandu Lansia Desa Jake Wilayah Kerja UPTD Kesehatan Kari Kabupaten Kuantan Singingi Tahun 2016}

Berdasarkan hasil penelitian dilapangan ditemukan bahwa ada hubungan yang bermakna antara status perkawinan dengan depresi pada lansia. Hal ini dapat disimpulkan bahwa status pasangan akan mempengaruhi depresi pada lansia dengan $p$ value 0,004 ( $p$ value $<0,05)$ dan nilai $\mathrm{OR}=7,377$.

Status perkawinan memiliki hubungan dengan kejadian depresi bahwa berlangsungnya pernikahan membawa manfaat yang baik bagi kesehatan mental laki-laki dan perempuan, pernikahan tidak hanya melegalkan hubungan asmara atara 
laki-laki denga perempuan karena ikatan suami istri ini juga dapat mengurangi resiko mengalami depresi dan kecemasan. Menurut hasil penelitian Ratna (2012), tentang hubungan pengetahuan, dan tatus perkawinan akan mempengaruhi kejadian depresi di Jakarta Selatan diketahui bahwa dengan $p$ value $=0,003$. Hal ini menyatakan bahwa ada hubungan antara status perkawinan dengan kejadian depresi pada lansia. Hasil penelitian ini sejalan juga dengan penelitian Sari (2012), yang menyatakan bahwa ada hubungan yang bermakna antara status perkawinan dengan kejadian depresi pada lansia dengan hasil analisa ( $p$ value $=0,001$ dan nilai $(\mathrm{OR}=4,105)$.

Menurut asumsi peneliti, terdapat 11 responden mempunyai pasangan mengalami depresi dikarenakan oleh adannya percekcokkan antara suami dan istri yang membuat emosional tidak terkontrol dan sehingga mengalami depresi sedangkan 34 responden yang tidak mempunyai pasangan mengalami depresi dikarenakan tidak adanya dukungan dari keluarga apa lagi pasangan sehingga tingkat emosional tidak terkontrol sehingga responden mengalami depresi.

\section{d. Hubungan Dukungan Keluarga dengan Depresi Pada Lansia di Posyandu Lansia Desa Jake Wilayah Kerja UPTD Kesehatan Kari Kabupaten Kuantan Singingi Tahun 2016}

Berdasarkan hasil penelitian dilapangan ditemukan bahwa ada hubungan yang bermakna antara dukungan keluaraga dengan depresi pada lansia. Hal ini dapat disimpulkan bahwa dukungan keluarga akan mempengaruhi depresi pada lansia dengan $p$ value 0,003 ( $p$ value $<0,05)$ dan nilai $\mathrm{OR}=7,728$.

Dukungan keluarga berhubungan erat dengan kejadian depresi pada lansia, yang mana keluarga yang enggan merawat lansia biasanya memilih menempatkan lansia ditempat penitipan orang tua atau sering disebut dengan panti lansia (Syukra, 2011). Menurut hasil penelitian Sarina (2012), tentang hubungan dukungan keluarga dan status perkawinan mempengaruhi depresi di Malang diketahui bahwa responden yang dukungan keluarga sebanyak $71(91,7 \%)$ dengan $\quad p$ value $=0,003$. Hal ini menyatakan bahwa ada hubungan antara dukungan keluaraga dengan kejadia depresi pada lansia.

Hasil penelitian ini sejalan juga dengan penelitian Mitha (2012), yang menyatakan bahwa ada hubungan yang bermakna antara dukungan keluaraga dengan depresi pada lansia dengan hasil analisa ( $p$ value $=0,001$ dan nilai $(\mathrm{POR}=$ $4,105)$. Menurut asumsi peneliti terdapat 11 responden ada dukungan keluarga mengalami kejadian depresi dikarenakan tidak adanya perhatian dan kasih sayang yang diberikan oleh keluarga kepada lansia atau responden mereka membiarkan lansia melakukan aktivitas sendiri sehingga lansia mengalami depresi, sedangkan 34 responden yang tidak ada dukungan dari keluarga mengalami kejadian depresi dikarenakan responden tidak mempunyai keluraga dan juga famili responden hidup sendiri sehingga mengalami kejadia depresi.

\section{KESIMPULAN DAN SARAN}

\section{Kesimpulan}

Berdasarkan hasil penelitian dan pembahasan diuraikan diatas, maka ditarik kesimpulan sebagai berikut :

1. Ada hubungan antara jenis kelamin dengan depresi pada lansia di Posyandu Lansia Desa Jake Wilayah Kerja UPTD Kesehatan Kari Kabupaten Kuantan Singingi

2. Ada hubungan antara pekerjaan dengan depresi pada lansia di Posyandu Lansia Desa Jake Wilayah Kerja UPTD Kesehatan Kari Kabupaten Kuantan Singingi

3. Ada hubungan antara status perkawinan dengan depresi pada lanisa di Posyandu Lansia Desa Jake Wilayah Kerja UPTD Kesehatan Kari Kabupaten Kuantan Singingi

4. Ada hubungan antara dukungan keluarga dengan depresi pada lansia di Posyandu Lansia Desa Jake Wilayah Kerja UPTD Kesehatan Kari Kabupaten Kuantan Singingi

\section{Saran}

1. Bagi kader posyandu lansia, diharapkan kepada kader posyandu lansia memberikan bimbingan dan arahan kepada lansia terhadap kejadian depresi yang bisa saja dialami oleh lansia. 
2. Bagi petugas pelayanan kesehatan, diharapkan kepada petugas kesehatan wilayah kerja UPTD Kesehatan Kari dapat memberikan informasi dan penyuluhan kepada lansia tentang kejadian depresi.

\section{DAFTAR PUSTAKA}

Amir, N. (2005). Depresi: neurobiology, diagnosis, tata laksana. Jakarta: balai penerbit FK UI.

BPS, BAPPENAS, UNFPA. (2005). Proyeksi Penduduk Indonesia 20002025. Jakarta.

Badan Pusat Statistik Kabupaten Kuantan Singingi, 2015. Statistik Daerah Kabupaten Kuantan Singingi. Teluk Kuantan

Dinas Kesehatan Kabupaten Kuantan Singingi. (2015). Profil Dinas Kesehatan

Departemen Kesehatan Republik Indonesia. (2004). Pedoman kesehatan jiwa usia lanjut (psikogeriatrik). Jakarta: Puskesmas Direktorat Jendral Pelayanan Medik.

Departemen Sosial RI, 2004, Undangundang Repebublik Indonesia No. 13, tahun 1998, tentang Kesejahteraan Lanjut Usia.

Hawari, D. (2007). Ilmu kedokteran jiwa dan kesehatan jiwa. Jakarta: Dana Bakti Prima Yasa.

Hidayat, A A. (2008). Metode Penelitian Keperawatan dan Teknik Analisis Data. Jakarta:Salemba Medika.

Martono, Heru, Gerakan Nasional Pemberdayaan Lanjut Usia, Gemari, Edisi 89, Tahun IX/Juni 2008.http://www.gemari.or.id/file/e disi88 (diakses 25 Mei2016)

Notoatmodjo. 2005. Metode Penelitian Kesehatan. Jakarta : PT Rineka Cipta

Notoatmodjo. (2007). Ilmu Kesehatan Usia Lanjut. Jakarta: FK UI.

Notoatmodjo. (2010). Metodologi Penelitian Kesehatan. Jakarta: Rineka Cipta

Nugroho. (2003). Perawatan Lanjut Usia. Edisi 3. Jakarta: EGC

Nugroho, W. (2006). Keperawatan gerontik dan geriatrik. Jakarta: Penerbit Buku Kedokteran EGC.

Nugroho, Wahjudi. (2008). Mengenal usia lanjut dan perawatannya. Jakarta : Salemba Medika.
Palestin. 2006. Ranah Penelitian Keperawatan Gerontik, (Online) http://repository.unand.ac.id. (diakses 05 Maret 2016).

Peters, R. 2004. Social Isolation and Loneliness. http://web.uvic.ca. (diakses tgl 05 Maret 2016).

Suwardiman, (2011). Hubungan antara dukungan keluarga dengan beban keluarga untuk mengikuti regimen terapuetik pada keluarga klien halusinasi RSUD Serang. Tesis Jakarta, FIK. Tidak dipublikasikan.

Syukra. A. (2012). Hubungan antara religiulitas dengan kejadian depresi pada lansia di Panti Sosial Tresna Werdha (PSTW) Sabai Nan Aluih Sicincin Kabupaten Padang Pariaman tahun 2012. Diperoleh pada tanggal 30 April 2016, dari http://repository.unand.ac.id/17930/ 2/ JOM Vol 2 No 2, Oktober 2015

Syamsuddin. (2006). Depresi pada Lansia. Diakses pada tanggal 22 Februari 2016 dari: http//www.depsos.go.id/modules.ph $\mathrm{p}$ ? name $=$ News $\&$ file $=$ article $\&$ sid $=2$ 08

Tamher, 2009, Kesehatan Usia Lanjut Dengan Pendekatan Asuhan Keperawatan, Salemba Medika, Jakarta.

WHO.(2006).http://www.WHO.int/featur e/factifiles/breastfeedeeding/en/inde x.html. diperoleh pada 22 Februari 2016. 